\title{
In-vitro Antioxidant and Oxidant Properties of Centaurea rigida
}

\author{
Eylem Kına $^{1, a, *}$, İmran Uysal ${ }^{1, b}$, Falah Saleh Mohammed ${ }^{2, c}$, Muhittin Doğan $^{1, d}$, Mustafa Sevindik $^{3, e}$ \\ ${ }^{1}$ Department of Biology, Faculty of Science and Literature, Gaziantep University, 27410 Gaziantep, Turkey \\ ${ }^{2}$ Department of Biology, Faculty of Science, Zakho University, Zakho, Iraq \\ ${ }^{3}$ Bahçe Vocational High School, Osmaniye Korkut Ata University, 80500 Osmaniye, Turkey
}

*Corresponding author

\begin{tabular}{l|l} 
A R T I C L E I N F O & A B S T R A C T \\
\hline Research Article & $\begin{array}{l}\text { Many different natural materials are used in complementary medicine. Among natural products, } \\
\text { herbal materials are used quite a lot. Centaurea rigida Willd. was used as material in this study. } \\
\text { The antioxidant and oxidant potential of the plant was determined. The aerial parts of the plant } \\
\text { sample were extracted with ethanol in a soxhlet device. Antioxidant and oxidant potentials were } \\
\text { measured with Rel Assay kits. As a result of the studies, the total antioxidant value of the plant was } \\
\text { determined as 3.522 } \pm 0.166, \text { the total oxidant value as } 15.424 \pm 0.281 \text { and the oxidative stress index } \\
\text { as } 0.440 \pm 0.020 . \text { It was determined that the plant has antioxidant potential, but its oxidant values are } \\
\text { heceived : } 01 / 08 / 2021\end{array}$ \\
Accepted : $30 / 08 / 2021$ & As a result, it was determined that $C$. rigida could be used as a natural antioxidant source.
\end{tabular}

Keywords:

Antioxidant

Asteraceae

Centaurea rigida

Medicinal Plants

Oxidant

\section{Introduction}

People face many disease factors at different stages of their lives. In this process, they benefit from complementary medicine as well as modern medicine. Many different natural materials are used in complementary medicine (Islek et al., 2021; Sarıdoğan et al., 2021). Plants have been used in the treatment of many diseases since ancient times. Many studies have shown that plants have many biological activities such as antioxidant, antimicrobial, anticancer, DNA protective, antiallergic, anti-inflammatory (Chandra, 2013; Sofowora et al., 2013; Gupta et al., 2016; Egamberdieva et al., 2017; Pehlivan). et al., 2018; Sevindik, 2018; Salehi et al., 2019; Li et al., 2020; Madani et al., 2021). Plants produce secondary metabolites in their bodies with environmental effects. These non-nutritive compounds are responsible for many biological activities. In particular, many plant species contain compounds with antioxidant properties (Soni et al., 2015; Jamwal et al., 2018; Cardoso et al., 2019; Salehi et al., 2020; Kaushik et al., 2021). In this context, it is very important to determine the antioxidant potential of plants. In this study, Centaurea rigida Willd. plant was used as material. The genus Centaurea is in the Asteraceae family. The family Asteraceae is a genus of 350 to 600 species of herbaceous thistle-like flowering plants. The genus Centaurea is distributed in different parts of the world (Caruso et al., 2013; Ranjbar and Negaresh, 2014). C. rigida used in our study is widely distributed in the Southeastern Anatolia region of Turkey. In this study, it was aimed to determine the antioxidant and oxidant potentials of the plant.

\section{Materials and Methods}

C. rigida samples were collected from Gaziantep (Turkey). Plant identification was made using Flora of Turkey volume 5 (Davis, 1975; 540). Plant samples were dried in a dry, shaded and ventilated area. Then, $30 \mathrm{~g}$ of the plant sample was cartridged and extracted with $200 \mathrm{~mL}$ of ethanol at $500 \mathrm{C}$ for about 6 hours. The solvents of the extracts obtained were removed in the condenser. (Heidolph Laborota 4000 Rotary Evaporator). 


\section{Total Antioxidant and Oxidant Tests}

Antioxidant (TAS) and oxidant values (TOS) of the plant sample were measured using Rel Assay kits. Calibrator trolox was used for TAS values and hydrogen peroxide was used for TOS values (Erel, 2004; Erel, 2005). The oxidative stress index was determined by the ratio of TOS values to TAS values (Sevindik, 2019).

\section{Results and Discussion}

\section{Antioxidant and Oxidant Status}

Living organisms produce reactive oxygen species under the influence of biotic and abiotic factors. As a result of the increase in the levels of these ROSs at the cellular level, oxidative stress occurs (Korkmaz et al., 2018). Antioxidant defense system functions in reducing the effect of oxidative stress. In cases where the antioxidant system is insufficient, taking products with antioxidant properties from outside reduces the effects of oxidative stress (Akgul et al., 2020). Plants are an important source of supplemental antioxidants (Bahmani et al., 2014). In this context, it is very important to investigate the antioxidant activities of plants in terms of their use. In this study, total antioxidant and total oxidant levels of $C$. rigida were determined. The obtained results are shown in Table 1.

Table 1. Antioxidant and Oxidant Status of Centaurea rigida

\begin{tabular}{l|c}
\hline \multicolumn{1}{c|}{ ????????? } & Centaurea rigida \\
\hline TAS & $3.522 \pm 0.166$ \\
TOS & $15.424 \pm 0.281$ \\
OSI & $0.440 \pm 0.020$ \\
\hline
\end{tabular}

Values are presented as mean \pm SD

Plants produce many biologically active compounds. Due to the antioxidant potential of some of these compounds produced in their structure, they are used as antioxidant sources in complementary medicine (Vanisree et al., 2004; Gobbo-Neto and Lopes, 2007). In this study, the antioxidant and oxidant potentials of $C$. rigida were determined for the first time. In a previous study, DPPH activity of $C$. rigida was reported as $70.813 \%$ (Duran et al., 2015). In addition, in studies on different plant species, TAS $(3.628 \mathrm{mmol} / \mathrm{L})$, TOS $(4.046 \mu \mathrm{mol} / \mathrm{L})$ and OSI (0.112) values of Mentha longifolia subsp. longifolia have been reported (Sevindik et al., 2017). TAS (6.831 mmol/L), TOS (3.712 $\mu \mathrm{mol} / \mathrm{L})$ and OSI (0.054) values of Gundellia tournefortii have been reported (Saraç et al., 2019). TAS $(6.758 \mathrm{mmol} / \mathrm{L})$, TOS $(5.802 \mu \mathrm{mol} / \mathrm{L})$ and OSI (0.086) values of Rumex crispus have been reported (Daştan et al., 2019). TAS (5.314 $\mathrm{mmol} / \mathrm{L})$, TOS $(24.199 \mu \mathrm{mol} / \mathrm{L})$, and OSI $(0.473)$ values of Scorzonera papposa have been reported (Mohammed et al., 2020a). TAS (7.677 mmol/L), TOS (12.387 $\mu \mathrm{mol} / \mathrm{L})$ and OSI (0.162) values of Marrubium globosum have been reported (Pehlivan et al., 2021). TAS (7.559 mmol/L), TOS $(10.711 \mu \mathrm{mol} / \mathrm{L})$ and OSI $(0.142)$ values of Datura stramonium have been reported (Mohammed et al., 2021). TAS $(5.688 \mathrm{mmol} / \mathrm{L})$, TOS $(15.552 \mu \mathrm{mol} / \mathrm{L})$ and OSI (0.273) values of Ferulago platycarpa have been reported (Mohammed et al., 2020b). TAS (5.853 mmol/L), TOS $(16,288 \mu \mathrm{mol} / \mathrm{L})$ and OSI (0.278) of Allium calocephalum have been reported (Mohammed et al., 2019). TAS (7.342 $\mathrm{mmol} / \mathrm{L})$, TOS $(5.170 \mu \mathrm{mol} / \mathrm{L})$, and OSI (0.071) of Rhus coriaria var. zebaria has been reported (Mohammed et al.,
2018). The TAS value is an indicator of the whole of the antioxidant compounds produced within the plant. The high TAS value indicates that the plant has a high level of antioxidant compounds (Mohammed et al., 2020c). In our study, TAS value of $C$. rigida was determined to be lower than G. tournefortii, R. crispus, S. papposa, M. globosum, D. stramonium, $F$. platycarpa, A. calocephalum, $R$. coriaria var. zebaria and $M$. longifolia subsp. longifolia. In this context, it was determined that the antioxidant potential of $C$. rigida used in our study has a lower antioxidant potential compared to the plants with TAS values in the literature. TOS values show the whole of the oxidant compounds produced by environmental factors in the plant. When these oxidant compounds increase at the cellular level, they can become harmful (Mohammed et al., 2020c). In this context, the TOS value of $C$. rigida was determined to be higher than $G$. tournefortii, $R$. crispus, M. globosum, D. stramonium, $R$. coriaria var. zebaria and M. longifolia subsp. longifolia, and lower than S. papposa, F. platycarpa and A. calocephalum. In this context, in our study, it was determined that the oxidant levels of $C$. rigida were higher. OSI values show how much the oxidant compounds produced in the plant are suppressed by antioxidant compounds. As the OSI value increases, it is seen that the plant is more affected by oxidant compounds (Mohammed et al., 2020c). The OSI value of $C$. rigida was lower than $S$. papposa and higher than $G$. tournefortii, $R$. crispus, M. globosum, D. stramonium, $F$. platycarpa, A. calocephalum, R.coriaria var. zebaria and $M$. longifolia subsp. longifolia. According to these results, due to the insufficiency of antioxidant compounds produced by C. rigida, it was insufficient to suppress oxidant compounds. On the other hand, it is thought that the above-ground parts of $C$. rigida samples collected from regions suitable for oxidative stress may be an antioxidant source.

\section{Conclusion}

In this study, antioxidant and oxidant potentials of $C$. rigida were determined. According to the findings, it was determined that the oxidant levels of the plant were high. In addition, antioxidant levels were found to be at normal levels. In addition, it is seen that the antioxidant defense system is insufficient in suppressing oxidant compounds. As a result, it is thought that $C$. rigida has antioxidant potential and samples collected from suitable regions in terms of oxidative stress may be a natural source.

\section{References}

Akgul H, Korkmaz N, Dayangaç A, Sevindik M. 2020. Antioxidant Potential of Endemic Salvia absconditiflora. Turkish Journal of Agriculture-Food Science and Technology, 8(10): 2222-2224.

Bahmani M, Golshahi H, Saki K, Rafieian-Kopaei M, Delfan B, Mohammadi T. 2014. Medicinal plants and secondary metabolites for diabetes mellitus control. Asian Pacific Journal of Tropical Disease, 4: S687-S692.

Cardoso JC, Oliveira ME, Cardoso FDC. 2019. Advances and challenges on the in vitro production of secondary metabolites from medicinal plants. Horticultura Brasileira, 37: 124-132.

Caruso G, Giardina AS, Raimondo FM, Spadaro V. 2013. A new species of Centaurea (Asteraceae) from Calabria (S Italy). Plant Biosystems-An International Journal Dealing with all Aspects of Plant Biology, 147(3): 844-848. 
Chandra M. 2013. Antimicrobial activity of medicinal plants against human pathogenic bacteria. International journal of biotechnology and bioengineering research, 4(7): 653-658.

Daştan SD, Durukan H, Demirbaş A, Dönmez E. 2019. Bioactivity and Therapeutic Properties of Evelik (Rumex crispus), A Naturally Growing and Edible Plant in Sivas Province. Turkish Journal of Agriculture-Food Science and Technology, 7(sp2): 67-71.

Davis PH. 1975. Flora of Turkey and the East Aegean Islands. Vol. 5. Edinburgh University Press, Edinburgh, UK

Duran A, Uslu N, Dogan B, Ozcan M, Çelik M. 2015. Antioxidant Activity and Phenolic Contents of 30 Selected Medicinal Plants. Journal of Agroalimentary Processes and Technologies, 21(2): 136-141.

Egamberdieva D, Wirth S, Behrendt U, Ahmad P, Berg G. 2017. Antimicrobial activity of medicinal plants correlates with the proportion of antagonistic endophytes. Frontiers in microbiology, 8: 199.

Erel O. 2004. A novel automated direct measurement method for total antioxidant capacity using a new generation, more stable ABTS radical cation. Clinical biochemistry, 37(4): 277-285.

Erel O. 2005. A new automated colorimetric method for measuring total oxidant status. Clinical biochemistry, 38(12): 1103-1111.

Gobbo-Neto L, Lopes NP. 2007. Medicinal plants: factors of influence on the content of secondary metabolites. Química Nova, 30(2): 374-381.

Gupta D, Dubey J, Kumar M. 2016. Phytochemical analysis and antimicrobial activity of some medicinal plants against selected common human pathogenic microorganisms. Asian Pacific Journal of Tropical Disease, 6(1): 15-20.

Islek C, Saridogan BGO, Sevindik M, Akata I. 2021. Biological Activities and Heavy Metal Contents of Some Pholiota Species. Fresenius Environmental Bulletin, 30(6): 6109-6114

Jamwal K, Bhattacharya S, Puri S. 2018. Plant growth regulator mediated consequences of secondary metabolites in medicinal plants. Journal of applied research on medicinal and aromatic plants, 9: 26-38.

Kaushik B, Sharma J, Kumar P, Shourie A. 2021. Phytochemical Properties and Pharmacological Role of Plants: Secondary Metabolites. Biosciences Biotechnology Research Asia, 18(1): 23.

Korkmaz AI, Akgul H, Sevindik M, Selamoglu Z. 2018. Study on determination of bioactive potentials of certain lichens. Acta Alimentaria, 47(1): 80-87.

Li Y, Kong D, Fu Y, Sussman MR, Wu H. 2020. The effect of developmental and environmental factors on secondary metabolites in medicinal plants. Plant Physiology and Biochemistry, 148: 80-89.

Madani H, Escrich A, Hosseini B, Sanchez-Muñoz R, Khojasteh A, Palazon J. 2021. Effect of Polyploidy Induction on Natural Metabolite Production in Medicinal Plants. Biomolecules, 11(6): 899.

Mohammed FS, Akgul H, Sevindik M, Khaled BMT. 2018. Phenolic content and biological activities of Rhus coriaria var. zebaria. Fresenius Environmental Bulletin, 27(8): 5694 5702 .

Mohammed FS, Günal S, Pehlivan M, Doğan M, Sevindik M, Akgül H. 2020b. Phenolic content, antioxidant and antimicrobial potential of endemic Ferulago platycarpa. Gazi University Journal of Science, 33(4): 670-677.

Mohammed FS, Günal S, Şabik AE, Akgül H, Sevindik M. 2020a. Antioxidant and Antimicrobial activity of Scorzonera papposa collected from Iraq and Turkey. Kahramanmaraş Sütçü İmam Üniversitesi Tarım ve Doğa Dergisi, 23(5): 1114-1118.
Mohammed FS, Karakaş M, Akgül H, Sevindik M. 2019. Medicinal properties of Allium calocephalum collected from Gara Mountain (Iraq). Fresenius Environmental Bulletin, 28(10): 7419-7426.

Mohammed FS, Kına E, Sevindik M, Dogan M, Pehlivan M. 2021. Datura stramonium (Solanaceae): Antioxidant and Antimicrobial Potentials. Turkish Journal of AgricultureFood Science and Technology, 9(4): 818-821.

Mohammed FS, Şabik AE, Doğan M, Selamoğlu Z, Sevindik M. 2020c. Antioxidant potential of Hypericum spectabile JAUB. ET SPACH. Bulletin of Biotechnology, 1(2): 43-45.

Pehlivan M, Mohammed FS, Sevindik M, Akgul H. 2018. Antioxidant and oxidant potential of Rosa canina. Eurasian Journal of Forest Science, 6(4): 22-25.

Pehlivan M, Mohammed FS, Şabik AE, Kına E, Dogan M, Yumrutaş Ö, Sevindik M. 2021. Some Biological activities of ethanol extract of Marrubium globosum. Turkish Journal of Agriculture-Food Science and Technology, 9(6): 1129-1132.

Ranjbar M, Negaresh K. 2014. A revision of Centaurea sect. Centaurea (Asteraceae) from Iran. Turkish Journal of Botany, 38(5): 969-987.

Salehi B, Gültekin-Özgüven M, Kırkın C, Özçelik B, MoraisBraga MFB, Carneiro JNP, Bezerra CF, da Silva TG, Coutinho HDM, Amina B, Armstrong L, Selamoglu Z, Sevindik M, Yousaf Z, Sharifi-Rad J, Muddathir AM, Devkota HP, Martorell M, Jugran AK, Martins N, Cho WC. 2019. Anacardium plants: chemical, nutritional composition and biotechnological applications. Biomolecules, 9(9): 465.

Salehi B, Gültekin-Özgüven M, Kirkin C, Özçelik B, MoraisBraga MFB, Carneiro JNP, Bezerra CF, da Silva TG, Coutinho HDM, Amina B, Armstrong L, Selamoglu Z, Sevindik M, Yousaf Z, Sharifi-Rad J, Muddathir AM, Devkota HP, Martorell M, Jugran AK, Cho W, Martins N. 2020. Antioxidant, antimicrobial, and anticancer effects of anacardium plants: an ethnopharmacological perspective. Frontiers in Endocrinology, 11: 295.

Saraç H, Demirbaş A, Daştan SD, Ataş M, Çevik Ö, Eruygur N. 2019. Evaluation of Nutrients and Biological Activities of Kenger (Gundellia tournefortii L.) Seeds Cultivated in Sivas Province. Turkish Journal of Agriculture-Food Science and Technology, 7(sp2): 52-58.

Saridogan BGO, Islek C, Baba H, Akata I, Sevindik M. 2021. Antioxidant Antimicrobial Oxidant and Elements Contents of Xylaria polymorpha and $\mathrm{X}$. hypoxylon (Xylariaceae). Fresenius Environmental Bulletin, 30(5): 5400-5404

Sevindik M. 2018. Pharmacological properties of Mentha species. J Tradit Med Clin Natur, 7(2): 259.

Sevindik M. 2019. Wild edible mushroom Cantharellus cibarius as a natural antioxidant food. Turkish Journal of AgricultureFood Science and Technology, 7(9): 1377-1381.

Sevindik M, Akgul H, Pehlivan M, Selamoglu Z. 2017. Determination of therapeutic potential of Mentha longifolia ssp. longifolia. Fresenius Environmental Bulletin, 26(7): 4757-4763.

Sofowora A, Ogunbodede E, Onayade A. 2013. The role and place of medicinal plants in the strategies for disease prevention. African journal of traditional, complementary and alternative medicines, 10(5): 210-229.

Soni U, Brar S, Gauttam VK. 2015. Effect of seasonal variation on secondary metabolites of medicinal plants. Int J Pharm Sci Res, 6(9): 3654-3662.

Vanisree M, Lee CY, Lo SF, Nalawade SM, Lin CY, Tsay HS. 2004. Studies on the production of some important secondary metabolites from medicinal plants by plant tissue cultures. Bot. Bull. Acad. Sin, 45(1): 1-22. 